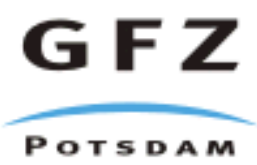

Originally published as:

Paton, D. A., di Primio, R., Kuhlmann, G., van der Spuy, D., Horsfield, B. (2007): Insights into the Petroleum System Evolution of the southern Orange Basins, South Africa. - South African Journal of Geology, 110, 2-3, 261-274

DOI: 10.2113/gssajg.110.2-3.261 


\title{
Insights into the Petroleum System Evolution of the southern Orange Basin, South Africa
}

\author{
Douglas. A. Paton \\ GeoForschungsZentrum Potsdam, Telegrafenberg, 14473 Potsdam, Germany \\ Present Address: School of Earth and Environment, University of Leeds. United Kingdom \\ email: douglas.paton@gmail.com \\ Rolando di Primio \\ GeoForschungsZentrum Potsdam, Telegrafenberg, 14473 Potsdam, Germany \\ email: dipri@gfz-potsdam.de \\ Gesa Kuhlmann \\ GeoForschungsZentrum Potsdam, Telegrafenberg, 14473 Potsdam, Germany \\ email: kuhlmann@gfz-potsdam.de \\ David van der Spuy \\ Petroleum Agency South Africa, Parow 7499, Republic of South Africa \\ email: vanderspd@petroleumagencysa.com \\ Brian Horsfield \\ GeoForschungsZentrum Potsdam, Telegrafenberg, 14473 Potsdam, Germany \\ email: horsf@gfz-potsdam.de \\ (C) 2007 September Geological Society of South Africa
}

\begin{abstract}
An integrated approach to investigate the petroleum system of the southern Orange Basin, South Africa reveals that the principal controls on hydrocarbon generation and leakage are spatial and temporal variations in post-rift overburden deposition. The model predicts present day gas seepage at the sea floor and this is calibrated against observed seepage events.

D basin modelling of an east-west trending transect across the Orange Basin passive margin was undertaken accounting for variations in stratigraphy, structural deformation, source rock distribution and characteristics and heat flow variations associated with continental break-up. Petroleum generation and migration modelling was performed using compositional kinetic schemes, and migration and leakage routes calibrated to signs of current-day active leakage collected during seismic interpretation. The use of seismic indicators of hydrocarbon leakage as calibration data for constraining migration predictions is essential for the reconstruction of hydrocarbon generation and migration scenarios, as they provide the validation of the model with respect both to the physical properties and distribution of the sedimentary sequences as well as the dynamics of oil and gas migration. Modelling results indicate that the main period of hydrocarbon generation occurred in the Late Cretaceous, the time of maximum burial on the shelf. Following an erosion event at the end of the Cretaceous, deposition shifted over the shelf break and significant sediment volumes prograded into the deep basin. This led to a second pronounced maturation event focussed specifically under the prograding Tertiary wedges. The model predicts that the kitchen area is active today and is also the source of hydrocarbons that are observed to be seeping at the present day sea floor.
\end{abstract}

\section{Introduction}

Natural hydrocarbon seepage is a process that is recognised to occur in varying intensity along most continental shelves. The seafloor expression of such seepage sites includes mud volcanoes (Dimitrov, 2002; Milkov, 2000), pock marks (Hovland and Judd, 1988) and carbonate mounds (Hovland and Thomsen, 1997; Naeth et al., 2005) while gas chimneys are seismic indications of vertical gas migration and are often related to these surface features (Heggland, 1997). The origin of present day free gas at the sediment-water interface is commonly attributed to either deep thermogenic hydrocarbon sources (Heggland, 1997; Limonov et al., 1997; MacDonald et al., 2000; Mazurenko et al., 2002) or the dissociation of gas hydrates (Cole et al., 2000; Van Rensbergen et al., 2002; Wood et al., 2002). Recently Parnell (2002) and Schlüter (2002) both independently indicated that more knowledge on fluid flow dynamics in sedimentary basins is a pre-requisite for understanding the driving forces and consequences of hydrocarbon seepage. Furthermore, the presence of seepage can be used to validate hydrocarbon system modelling, although this remains an underutilised technique. 


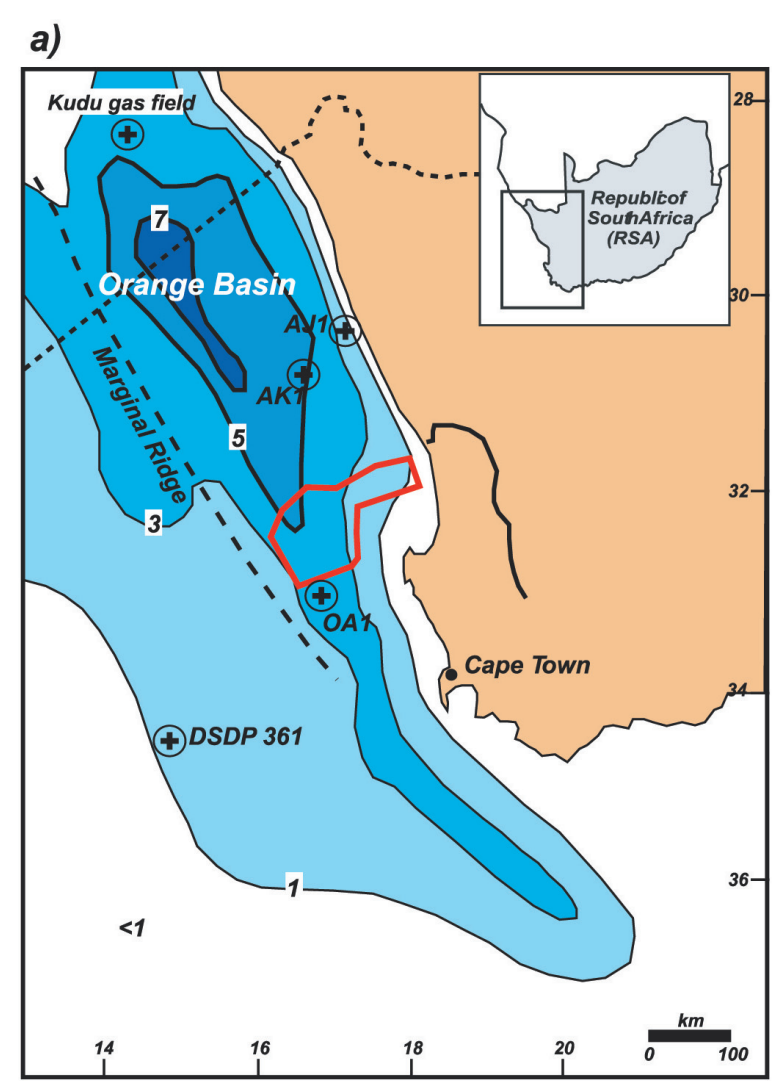

\section{b)}

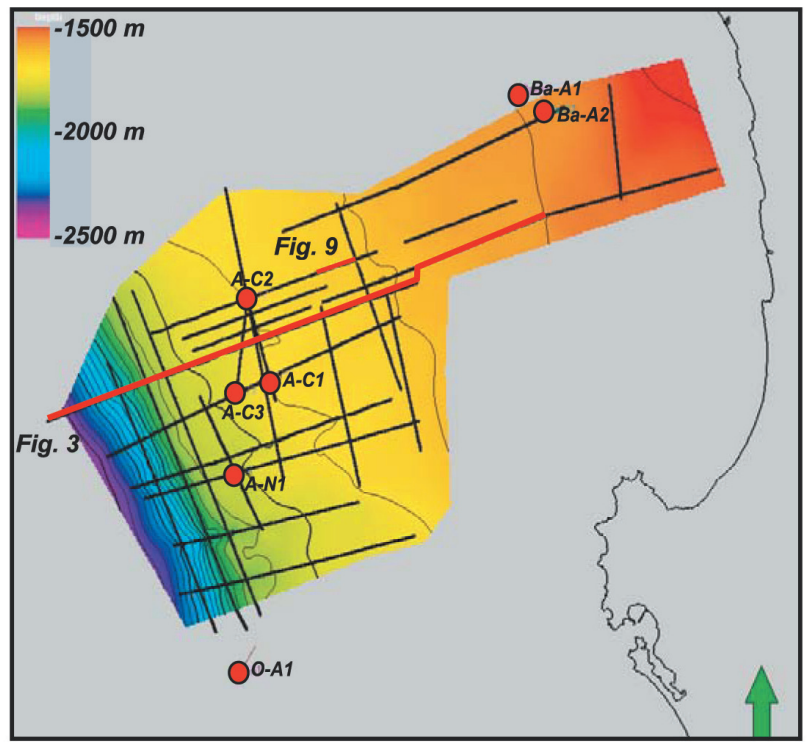

Figure 1. (a) Orange Basin location map with superimposed isopach distribution of post-rift strata (after Jungslager, 1999) showing the main depocentre, the marginal high and the wells referred to in the text. (b) Study area with borehole locations and seismic lines with superimposed bathymetry. The studied cross section used in this study is indicated in red (Figure 3).

Mud volcanoes, pock marks and possibly cold-water corals have been observed within the post-rift strata of the Orange Basin, South Africa (Figure 1) and attributed to gas escape features. The origin of the free gas has been attributed both to the dissociation of gas hydrates and to the underlying hydrocarbon system. The former has been suggested because of the direct association of the features with the BSR (Bottom Simulating Reflector) outcrop on the sea floor, while the latter has been proposed because of the occurrence of the features immediately above deeper seated structures (Ben Avraham et al., 2002). However, as there is no evidence of gas hydrates in ODP Leg 175 (Sites 1085, 1086 and 1087; Wefer et al., 1998) within the Orange Basin, the leaking gas has been considered primarily to be thermogenic in origin and sourced from the underlying hydrocarbon system. Although a number of studies have investigated the Orange Basin, including both its sequence stratigraphic (Gerard and Smith, 1982; Dingle, 1983); Muntingh and Brown, 1993; Brown et al., 1995) and petroleum system elements (Jungslager, 1999) there has been no integration of petroleum modelling with leakage events.

This study aims to integrate observations of gas leakage from 2D petroleum system modelling of the southern Orange Basin (Figure 1b) derived from integration of seismic interpretation, and structural and stratigraphic analysis studies. The results presented utilise the interpretation of 22 2D seismic lines and data from seven wells supplied by the Petroleum Agency SA.

In this study we demonstrate: 1) the evolution of hydrocarbon generation, migration and accumulation; 2) the relationship between gas leakage and thermogenic gas migration and; 3) the use of free gas indicators to calibrate migration model predictions.

\section{Regional Setting}

The Orange Basin is the quintessential passive margin that formed during the break up of Gondwana and the subsequent rifting/drifting of the South Atlantic Ocean. The syn-rift portion of the basin is characterized by a series of grabens and half-grabens that trend approximately parallel to the present day margin. The syn-rift fill, which is Upper Jurassic and Lower Cretaceous in age, predominantly comprises siliciclastic and lacustrine strata with a widespread occurrence of volcanic sequences (Figure 2). Most of the syn-rift sequences were deposited immediately to the east of the marginal ridge and within isolated half-grabens on the middle and inner shelf.

The post-rift sequence has a greater than $7 \mathrm{~km}$ thick post-rift Barremian/Lower Aptian to present day interval 


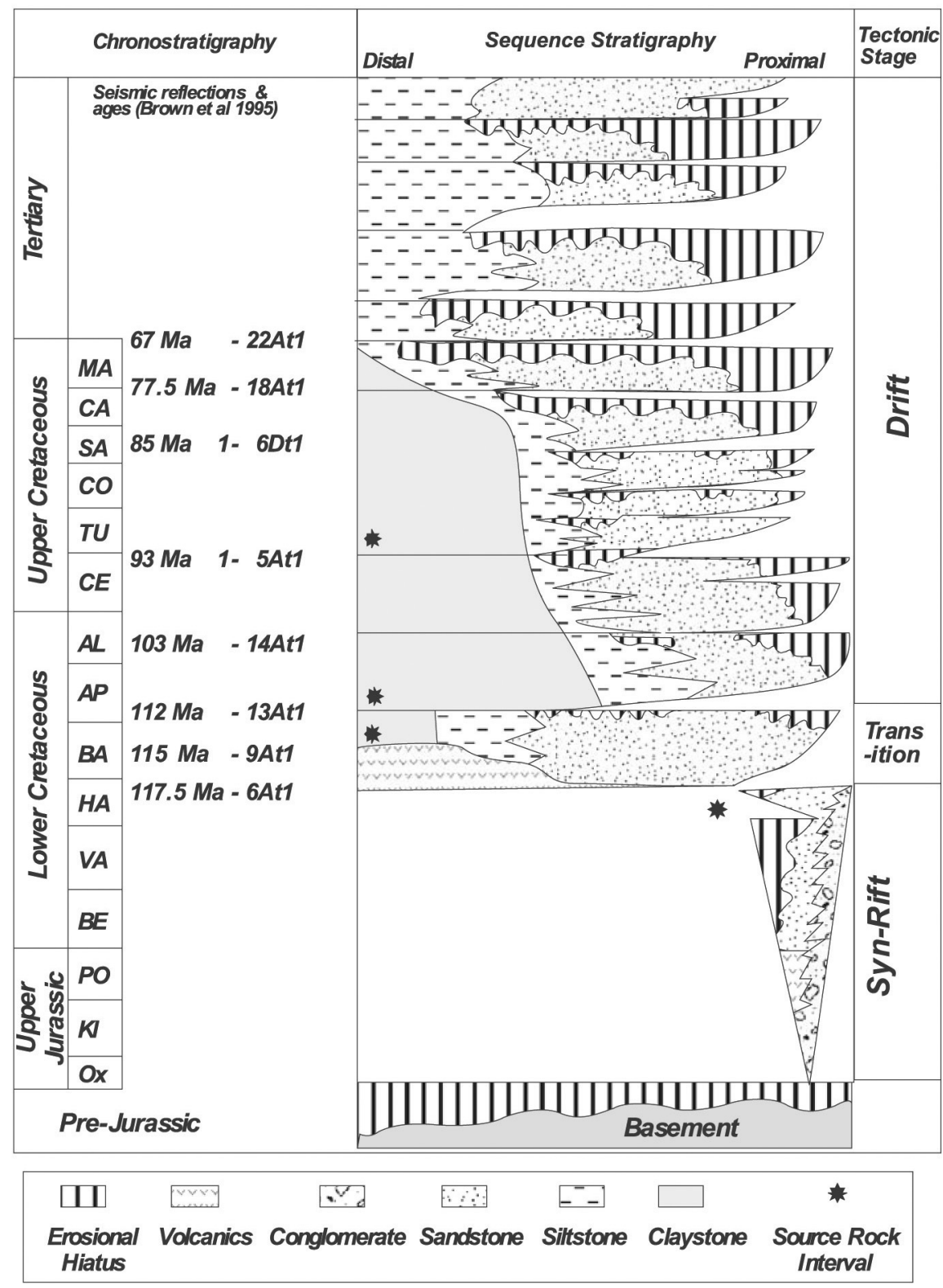

Figure 2. Chronostratigraphic and sequence stratigraphic diagram for the Orange Basin including the seismic horizons and corresponding ages used in this study (after Brown et al., 1995).

that thins to an approximately $3 \mathrm{~km}$ thick sequence in the study area in the south (Gerard and Smith, 1983; Figure 1). The Barremian/Lower Aptian sequence corresponds to a transitional phase between syn-rift and drift during which time period the highest quality source rock was deposited; this sequence was penetrated by DSDP 361 (Herbin et al., 1987) that demonstrated the interval was at least $300 \mathrm{~m}$ thick with TOCs of up to $25 \%$. This sequence is overlain by more than $5500 \mathrm{~m}$ of Upper Cretaceous shales and claystones that are relatively undeformed. The overlying Cenozoic strata were deposited basin-ward of the Cretaceous sequence with a thickness of greater than $1500 \mathrm{~m}$ towards the outer margin.

\section{Margin transect}

Muntingh and Brown (1993) and Brown et al. (1995) established a sequence stratigraphic and biostratigraphic framework for the Orange Basin based on twenty-two basin-wide sequence stratigraphic unconformities. The framework was used as the basis of this study and simplified to eight unconformities that adequately demonstrate margin evolution. This study used the terminology of Muntingh and Brown (1993), e.g. 6At1, for defining unconformities with reflections defining the top of the corresponding sequence (e.g. 6At1 defines the top of event 29; Table 1). These were used to outline the main events forming the petroleum system model (Figures 2 and 3). These unconformities were 
Table 1. Event, age and facies definition of the $2 \mathrm{D}$ model.

\begin{tabular}{|c|c|c|c|c|c|c|}
\hline Name_Events & $\begin{array}{c}\text { Deposition } \\
\text { Age from (Ma) }\end{array}$ & $\begin{array}{l}\text { Deposition } \\
\text { Age to (Ma) }\end{array}$ & $\begin{array}{c}\text { Erosion } \\
\text { Age from (Ma) }\end{array}$ & $\begin{array}{c}\text { Erosion } \\
\text { Age to }(\mathrm{Ma})\end{array}$ & Facies 1 & Facies 2 \\
\hline 22At1_43_49 & 67.00 & 0.00 & 0.00 & 0.00 & Claystone & - \\
\hline Erosion_40_42 & 77.00 & 72.00 & 72.00 & 67.00 & Claystone & - \\
\hline 18At_39_40 & 80.00 & 77.00 & 0.00 & 0.00 & Claystone & - \\
\hline 16Dt_37_38 & 85.00 & 80.00 & 0.00 & 0.00 & Claystone & - \\
\hline 15At_36 & 93.00 & 85.00 & 0.00 & 0.00 & Claystone & - \\
\hline 14At_35 & 100.00 & 93.00 & 0.00 & 0.00 & Claystone & - \\
\hline 14At_34 & 103.00 & 100.00 & 0.00 & 0.00 & sandstone & Claystone \\
\hline 13At1_14At_33 & 108.00 & 103.00 & 0.00 & 0.00 & Claystone & - \\
\hline 13At1_32 & 112.00 & 108.00 & 0.00 & 0.00 & Source_3_Aptian & Source_3a_Aptian \\
\hline 9At1_31 & 114.00 & 112.00 & 0.00 & 0.00 & Sandstone & - \\
\hline 9At1_30 & 115.00 & 114.00 & 0.00 & 0.00 & Source_2_Barremian & - \\
\hline 6At1_29 & 117.50 & 115.00 & 0.00 & 0.00 & Sandstone & Shale \\
\hline Synrift_24_28 & 121.25 & 117.50 & 0.00 & 0.00 & Sandstone & Shale \\
\hline Synrift_23 & 121.50 & 121.25 & 0.00 & 0.00 & Source_1_Synrift & Sandstone \\
\hline Synrift_22 & 122.00 & 121.50 & 0.00 & 0.00 & Sandstone & - \\
\hline Synrift_21 & 122.50 & 122.00 & 0.00 & 0.00 & Source_1_Synrift & Sandstone \\
\hline Synrift_19_20 & 122.70 & 122.50 & 0.00 & 0.00 & Sandstone & - \\
\hline Synrift_17_18 & 123.00 & 122.70 & 0.00 & 0.00 & Source_1_Synrift & Sandstone \\
\hline Synrift_14_16 & 123.50 & 123.00 & 0.00 & 0.00 & Sandstone & - \\
\hline Synrift_12_13 & 124.00 & 123.50 & 0.00 & 0.00 & Source_1_Synrift & Sandstone \\
\hline Synrift_10_11 & 124.38 & 124.00 & 0.00 & 0.00 & Sandstone & - \\
\hline Synrift_8_9 & 124.46 & 124.38 & 0.00 & 0.00 & Source_1_Synrift & Sandstone \\
\hline Event_3_7 & 125.00 & 124.46 & 0.00 & 0.00 & Sandstone & - \\
\hline Basement_1_2 & 200.00 & 125.00 & 0.00 & 0.00 & Basement & - \\
\hline
\end{tabular}

recognised in five boreholes, tied to the seismic reflection data and correlated across the working area. Additionally, the wells provided litho stratigraphic and age constraints for the sequences as well as temperature and vitrinite reflectance data and paleo-water depths for model calibration.

The west-east transect across the southern portion of the Orange Basin (Figure 3) reveals that the syn-rift interval is limited to the outer part of the basin. However, this part is poorly constrained by the seismic data as it extends to depths greater than the maximum recording depth $6000 \mathrm{~ms}$ TWT. In the middle and inner shelf region there is only a very thin syn-rift package (beneath reflection 6At1) that occurs between the Paleozoic basement and the Cretaceous post-rift strata.

The Cretaceous post-rift package can be divided into a lower package (between reflections 6At1 and 16Dt1) that has both progradational and aggradational internal reflection geometry and an upper package that is dominated by an aggradational geometry (between reflections 16Dt1 and 22At1). The detailed architectural stacking pattern of the sequences has been extensively documented by Muntingh and Brown (1993) and Brown et al., (1995). For the purposes of the petroleum system modelling in this study only the gross architecture of the margin section (Figure 3) is important. The thickness of both of units vary significantly across the margin with much greater thickness on the inner and middle shelf (lower and upper 1200 to $1500 \mathrm{~m}$ ) compared to the outer shelf (lower and upper - $800 \mathrm{~m}$ ).

The top of the Cretaceous package is characterised by erosional truncation beneath the 22At1 reflection with the amount of erosion varying from zero in the western part of the basin to greater than $600 \mathrm{~m}$ in the inner shelf (Figure 3). The age of the erosion is post deposition of the $18 \mathrm{At} 1$ reflection $(77.5 \mathrm{Ma})$ and older than the 22At1 reflection (67 Ma).

In contrast, the Cenozoic sequence is very thin on the middle and inner shelf reaching a maximum of 400 $\mathrm{m}$, while there is over $2000 \mathrm{~m}$ of accumulation in the outer margin. The deposition of this sequence is dominated by the development of growth faults and toethrusts (Figure 3).

\section{Petroleum System Modelling}

The margin transect outlined in the previous section, having been depth converted using borehole velocity profiles, formed the basis of the petroleum system input model (Figure 3c, Table 1) using Petromod Vs. 8 and 9 software (IES GmbH, Germany). The section was discritized into 45 vertical cells of $1.5 \mathrm{~km}$ width and 49 horizontal events. These events were defined initially by the individual depositional or erosional sequence boundaries and the intermediate events were defined in order that no time step had a duration of greater than $10 \mathrm{Ma}$. The principal components of the hydrocarbon 
system outlined below were then defined in the model input.

\section{Source rock intervals}

A number of both proven and inferred source rocks have been identified within the basin (Jungslager, 1999; van der Spuy, 2003), including:

1. syn-rift lacustrine intervals; 2. transitional Barremian and marine lower Aptian; and 3. a Cenomanian/ Turonian maximum flooding event.

1. The proven syn-rift source interval comprises late Hauterivian lacustrine deposits within the half-graben penetrated by the AJ1 well and is oil prone with TOC $>10 \%$ and $\mathrm{HI}$ of $>600 \mathrm{mg} \mathrm{HC} / \mathrm{g}$ (Barton et al., 1993; Muntingh, 1993). Although this interval has been proven only at this well, regional correlations and



Figure 3. (a) East-west seismic cross-section across the study area showing the principal seismic stratigraphic sequences. The location of the section is given in figure 1. The black rectangles mark the location of Figure 8. (b) Interpreted schematic cross-section (in TWT) indicating the potential source rock intervals (black lines with star) and chronostratigraphic intervals. (c) Depth converted model of Figure $3 \mathrm{a}$ input of the cross-section with facies definitions for each unit. In addition, the lateral variation of the stretching factor is shown. 
Table 2. Facies definitions used in the $2 \mathrm{D}$ model

\begin{tabular}{|c|c|c|c|c|c|}
\hline \multicolumn{6}{|l|}{ Definitions } \\
\hline Facies & $\begin{array}{l}\text { Petroleum } \\
\text { elements }\end{array}$ & Lithology & $\begin{array}{l}\text { TOC } \\
\left(w t^{\circ} \%\right)\end{array}$ & Kinetics & $\begin{array}{c}\text { HI } \\
\text { (mgHC/gTOC) }\end{array}$ \\
\hline Claystone & Overburden rock & Leaky shale & 0.00 & None & 0 \\
\hline Shale & Overburden rock & Shale & 0.00 & None & 0 \\
\hline Sandstone & Reservoir rock & Sandstone & 0.00 & None & 0 \\
\hline Source_3a_Aptian & Source rock & Silt and sand & 10.00 & Pepper \& Corvi(1995)_Type II & 300 \\
\hline Source_3_Aptian & Source rock & Shale & 10.00 & Pepper \& Corvi(1995)_Type II & 300 \\
\hline Source_2_Barremian & Source rock & Shale & 10.00 & Pepper \& Corvi(1995)_Type III & 150 \\
\hline Source_1_Synrift & Source rock & Shale & 12.00 & Pepper \& Corvi(1995)_Type & I 700 \\
\hline Basement & Underburden rock & Basement & 0.00 & None & 0 \\
\hline
\end{tabular}

reconstructions with the South American margin suggest that the interval is significantly more extensive (Jungslager, 1999).

2. The Barremian-lower Aptian sequence is a proven gas and oil source interval that is commercially producing gas in Kudu field and is a proven gas play in well AK1. In a more distal location it is oil prone with a $40 \mathrm{~m}$ interval documented in OA1 containing $26 \%$ TOC and an HI of 180-200 mg HC/g (Jungslager, 1999; van der Spuy, 2003). It has also been penetrated by DSDP 361 where a $300 \mathrm{~m}$ thick interval had TOC up to $25 \%$ and $\mathrm{HI}$ of $800 \mathrm{mg} \mathrm{HC} / \mathrm{g}$.

3. The Cenomanian-Turonian maximum flooding surface is the most speculative although gas was encountered in the AK1 well and its has been suggested to be oil prone down dip to the east (van der Spuy, 2003).

Kinetic models were assigned to source rock intervals based on the source rock facies (Table 2) and accounted for both primary and secondary cracking (Pepper and Corvi, 1995a; 1995b; Pepper and Dodd, 1995).

\section{Stratigraphic variations}

The principal stratigraphic variations, derived from tying borehole data to the seismic data, for the modeling are: 1. the inferred presence of terrestrial sands and lacustrine sediments in the syn-rift interval;

2. the deltaic sediments that prograded from east to the west (oceanward) between time events 6At1 and 13At1 with a sand prone component in the proximal (east) and more silt prone to the west;

3. the transition from the deltaic succession to an aggrading margin sequence between 13At1 and 15At1 that is dominated by silt and sand-silt.

Overlying the 15At1 reflection, the lithology is dominated by claystone until the present day. The physical parameters for the lithologies in our model are given in Table 3. The high quality of the seismic reflection data, coupled with available borehole data, result in a well constrained stratigraphic model. The greatest uncertainty occurs within the syn-rift interval where there is either poor seismic data or it is below the maximum recording depth. The geometry of the interval is inferred from published data on the portions of the margin where the interval is evident (Jungslager, 1999). As the hydrocarbon modelling demonstrates below, the specific geometry of the syn-rift interval is not critical to this study.

\section{Heat flow}

Heat flow scenarios were modelled using a McKenzietype lithospheric stretching model (McKenzie, 1978) with beta factors ranging from 1.5 to 2.5 and a $10 \mathrm{Ma}$ duration rift event starting at $130 \mathrm{Ma}$ followed by a thermal decay over $70 \mathrm{Ma}$ with constant rates up to the present (Figure 4). In the middle shelf area vitrinite reflectance data were used to calibrate the heat flow modelling (Figure 5) based on the kinetics for vitrinite maturation defined by Sweeney and Burnham (1990). Using these kinetics, regardless of the heat flow scenario used including unrealistic ones, it was impossible to obtain a vitrinite model that reproduced all of the observed vitrinite data. The best fit was obtained with a stretching factor of $\sim 2$ that matched the observed data at the minimum and maximum depth but resulted in a mis-match in the middle (between 1400 and $2600 \mathrm{~m}$; Figure 5). This mis-match could not be account for by erosion, reworking, abnormal heat flow histories, or by changing the physical or thermal properties of the rock unit, therefore, it was out with the scope of the study to investigate the cause of the mis-match. The best fit model that was used also required approximately $800 \mathrm{~m}$ of erosion in the Late Cretaceous, which is in agreement with the observations from the regional transect. Although other unconformities are present within the strata they are minor (e.g. 15At1 $\sim 10 \mathrm{~m}$ ) and have no significant effect on the heat flow evolution.

As the only data for heat flow calibration are in the middle shelf then the heat flow for the remainder of the margin had to be estimated. Given that the transect consists of a passive margin with little evidence of crustal extensional in the east and significant extension oceanward, as demonstrated by sea-ward dipping reflections further west, then a progressive increase in stretching factor from 1.5 in the east to 2.5 in the west was assumed (Figure 3c). Although these stretching factors were used for the initial model, sensitivity 


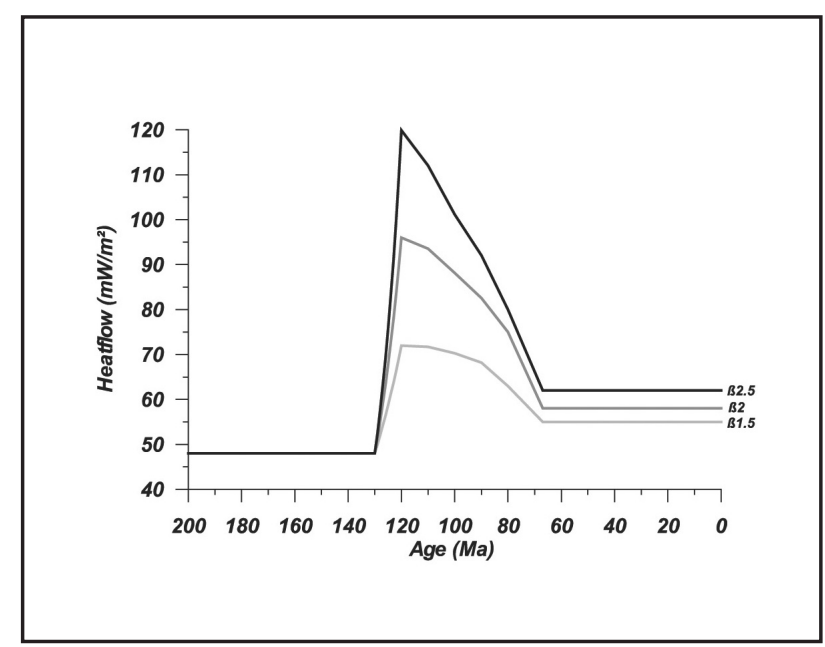

Figure 4. Heatflow histories for the stretching factors as used in the modelled cross section. The lateral distribution of the different heatflow curves in the model cross-section is indicated in Figure 3c. analysis was undertaken and is discussed in a later section.

\section{Paleo-water depth and sea-surface temperature}

Paleo-water depth evolution was based on the sequence stratigraphic interpretation. At each timestep it was assumed that the clinoform geometry consists of a horizontal top set, seaward dipping foreset and horizontal bottom set. The location of the topset was consistently within the middle and inner shelf area where absolute paleo-water depth was constrained by Petroleum Agency SA paleontological data. In the outer shelf area there is no evidence from boreholes, therefore, the paleo-water depth has only been inferred from the geometry of the depth-converted margin clinoforms. The resultant paleo-water depth was calculated for each time step and was accounted for in the petroleum model.

Sea surface temperatures were calculated based on paleo-latitude as defined by Wygrala (1989). Sea floor

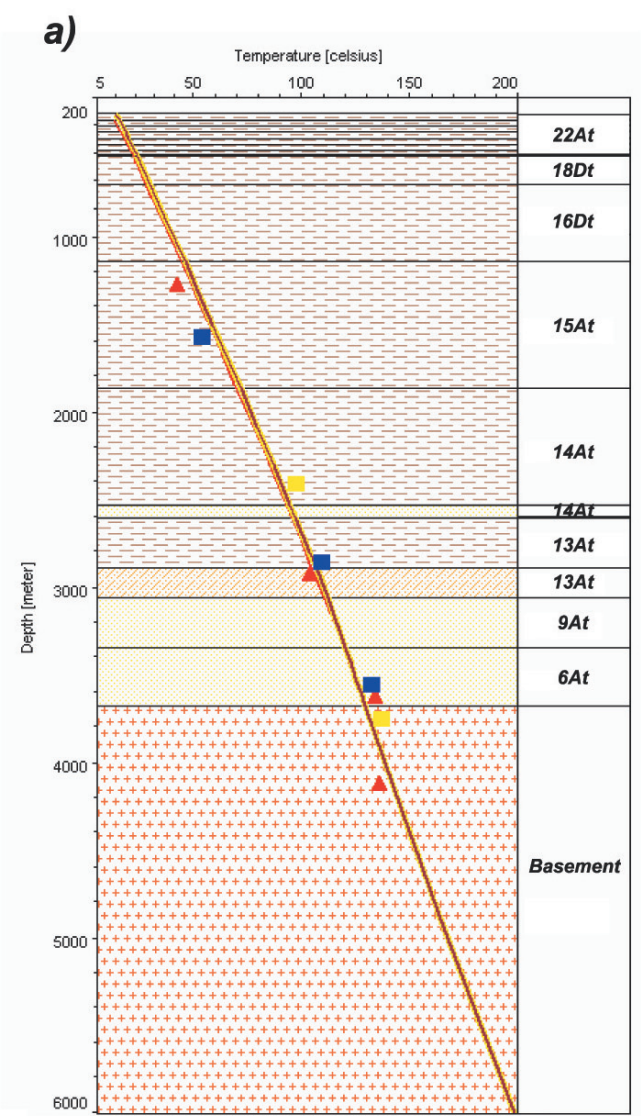

$A C 1$
$A C 2$
$A C 3$

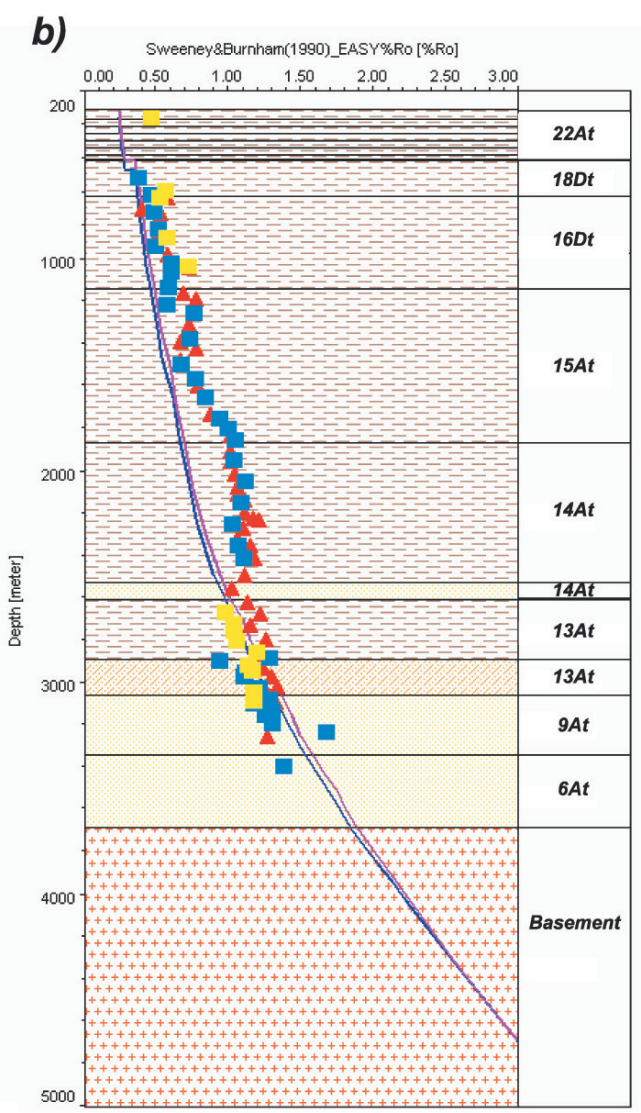

AC1

Figure 5. Observed variations of (a) temperature and (b) vitrinite reflectance are plotted for wells AC1, 2 and 3 . The best fit lines for vitrinite reflectance derived from kinetic modelling are shown. Although this is the best fit there is an obvious mismatch at depths of 1400 to $2600 \mathrm{~m}$, see text for discussion. 
a)

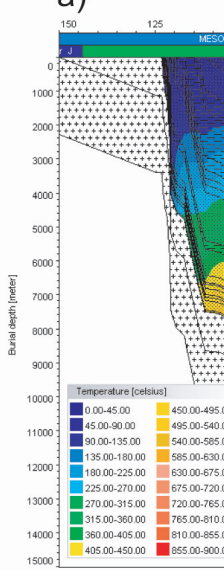

b)

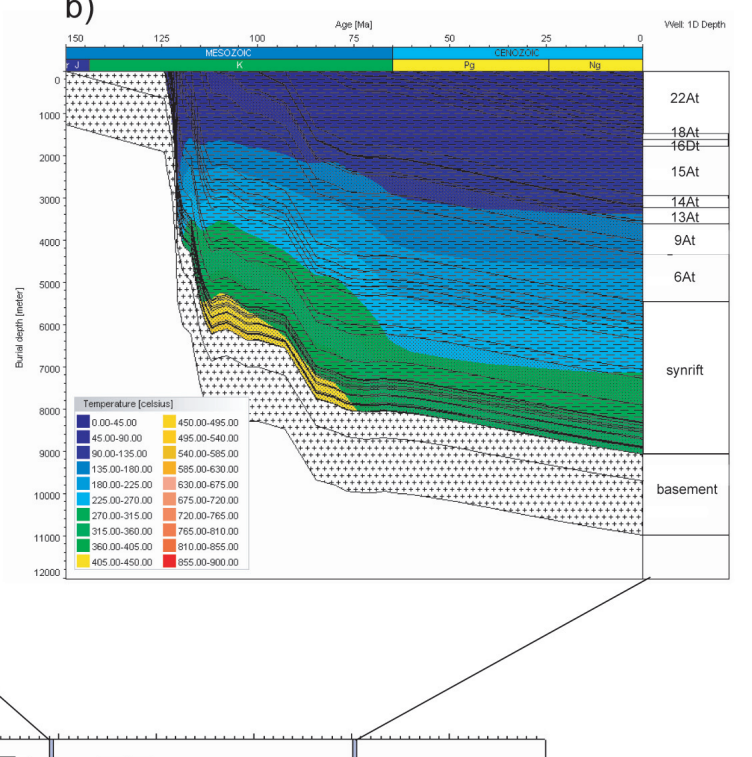

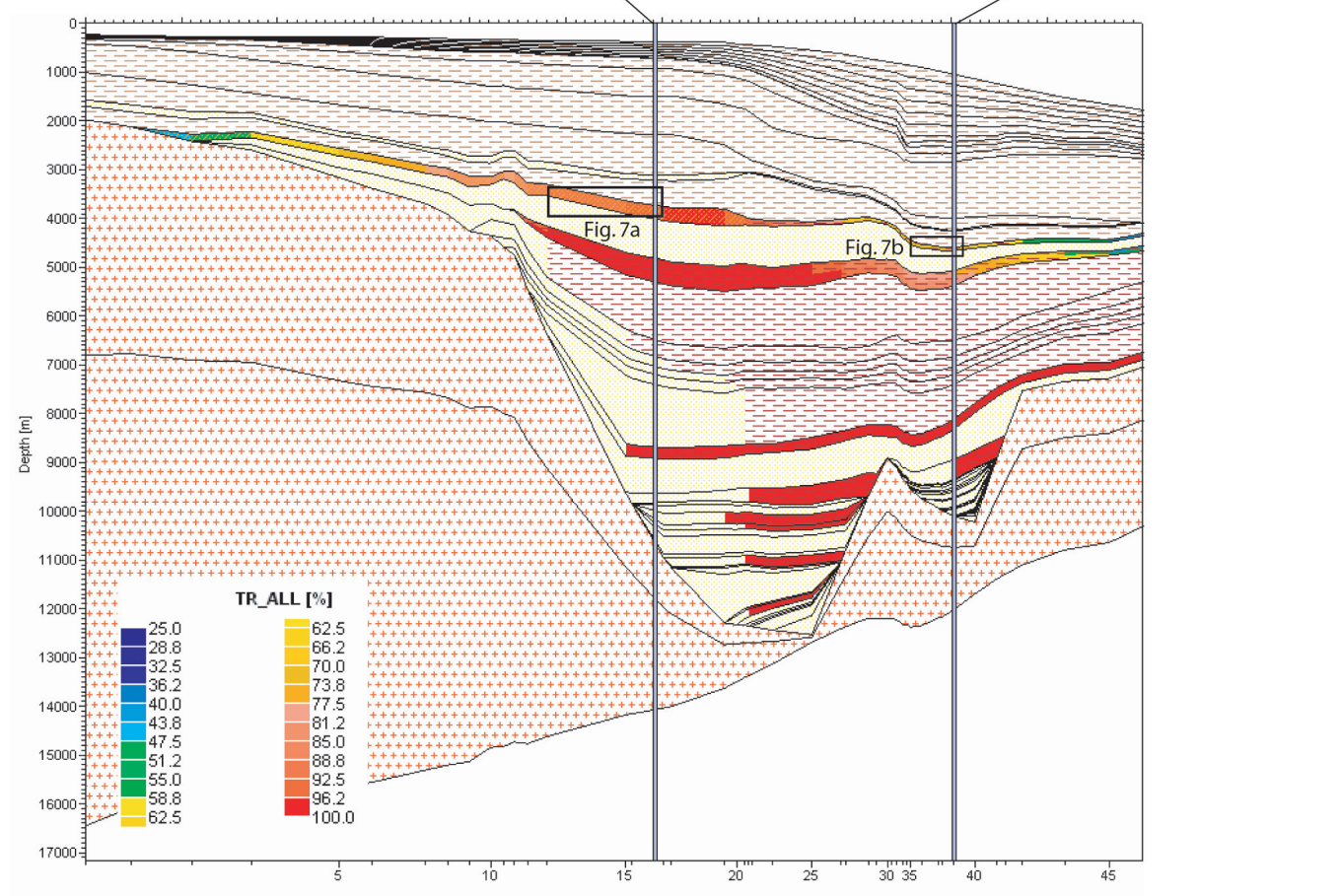

Figure 6. Model results indicating the thermal history of the marginal-cross section, (a) Burial history with temperature overlay at location with erosion at K/T-boundary, (b) Burial history at location with thick Tertiary sediment accumulations.

temperatures were calculated as being water depth dependant assuming a $1^{\circ} \mathrm{C}$ decrease in the first $100 \mathrm{~m}$, $2^{\circ} \mathrm{C}$ decrease per $100 \mathrm{~m}$ up to $200 \mathrm{~m}$ water depth, $3^{\circ} \mathrm{C}$ decrease per $100 \mathrm{~m}$ up to $300 \mathrm{~m}$ and then extrapolated to a temperature of $4^{\circ} \mathrm{C}$ at $1000 \mathrm{~m}$. Below $1000 \mathrm{~m}$ water depth water temperature was assumed constant at $4^{\circ} \mathrm{C}$. In the above the $4^{\circ} \mathrm{C}$ temperature was assumed to be representative of average polar water conditions, which obviously changed through geologic time. For individual time steps average polar water temperatures were defined based on the latitude-dependant global mean temperature assessment of Wygrala (1989) and temperature gradients in the water column calculated as described above.

\section{Summary of $2 \mathrm{D}$ results Maturation bistory}

The initial model results reveal a significant lateral variation in the degree of kerogen conversion (transformation ratio, Tr) for the present day (Figure 6). 


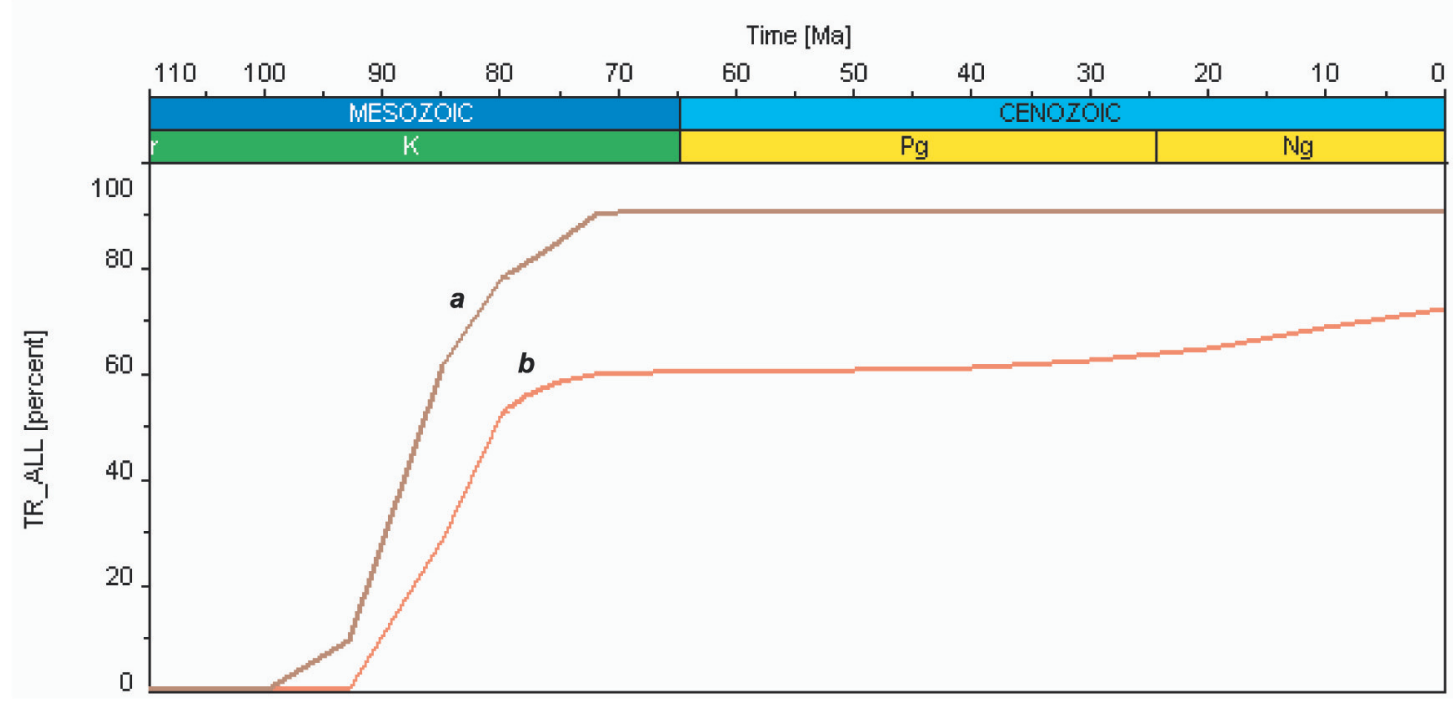

Figure 7. Model results representing the maturation history of the Albian source rocks, (a) Transformation ratio (Tr) over time at location with erosion at K/T-boundary, (b) Transformation ratio (Tr) over time at location with thick Tertiary sediment accumulations.

The entire syn-rift source interval has a $\operatorname{Tr}$ of $100 \%$ indicating complete kerogen conversion; it is, therefore, unimportant with respect to present day hydrocarbon generation. Although the Barremian and Aptian sources have variable extents of conversion at present day, the degree of transformation does not closely correlate to overburden sediment thickness suggesting that present day burial depth is not the principal main control. The burial histories of two extracted gridpoints of the 2D model demonstrate that the temperature field evolution across the transect is strongly influenced by: a) the late Cretaceous erosion in the middle and inner shelf; and b) the prograding Tertiary wedge in the outer shelf (Figure $6 \mathrm{a}$ and b). Transformation ratios, and hence hydrocarbon generation, are considered to be controlled at a first order by the burial history.

The variation of source rock generation in a temporal context is best illustrated by the Aptian source

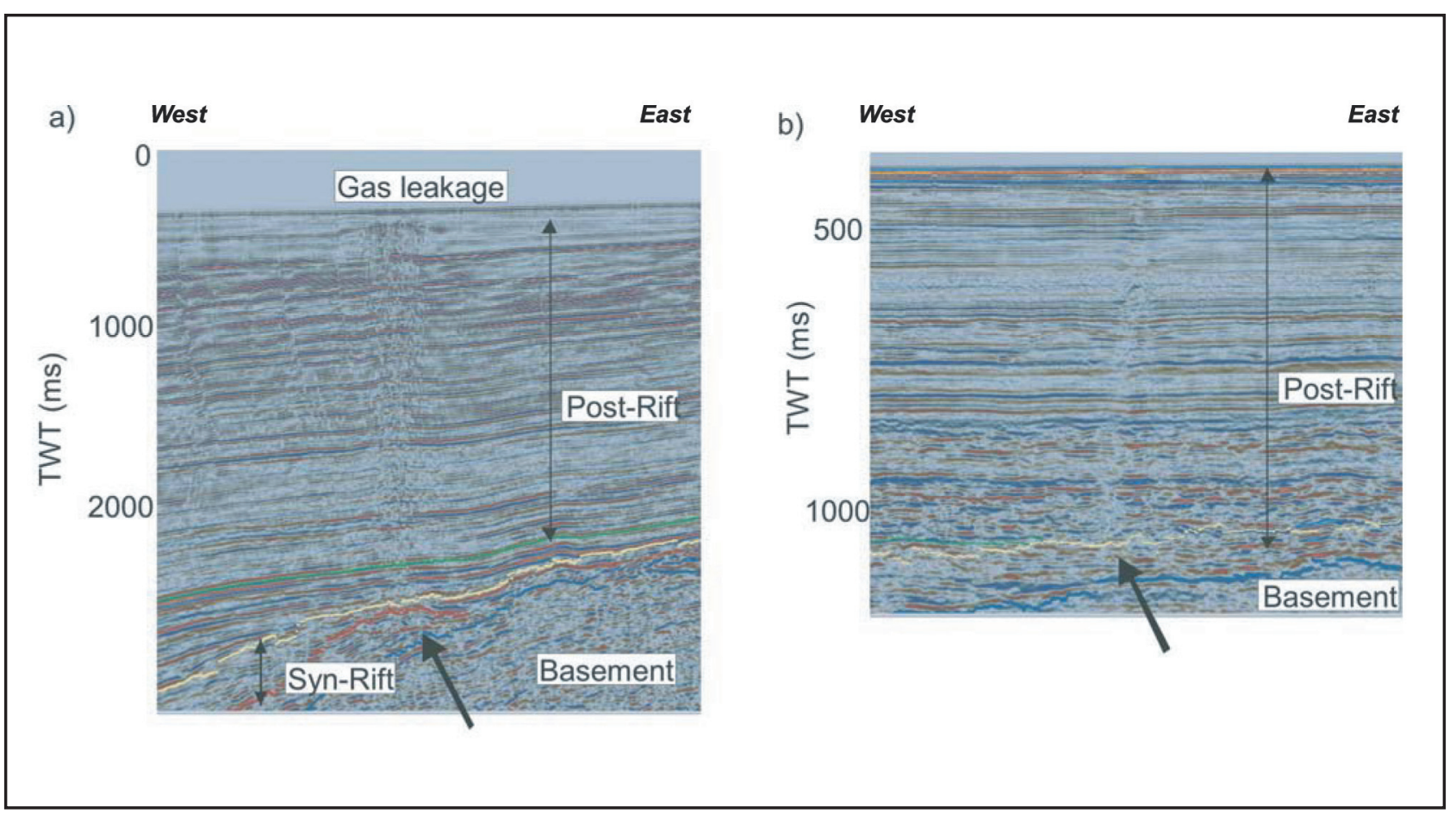

Figure 8. Seismic evidence of gas leakage associated with (a) syn-rift structural closure and (b) stratigraphic pinchout. 


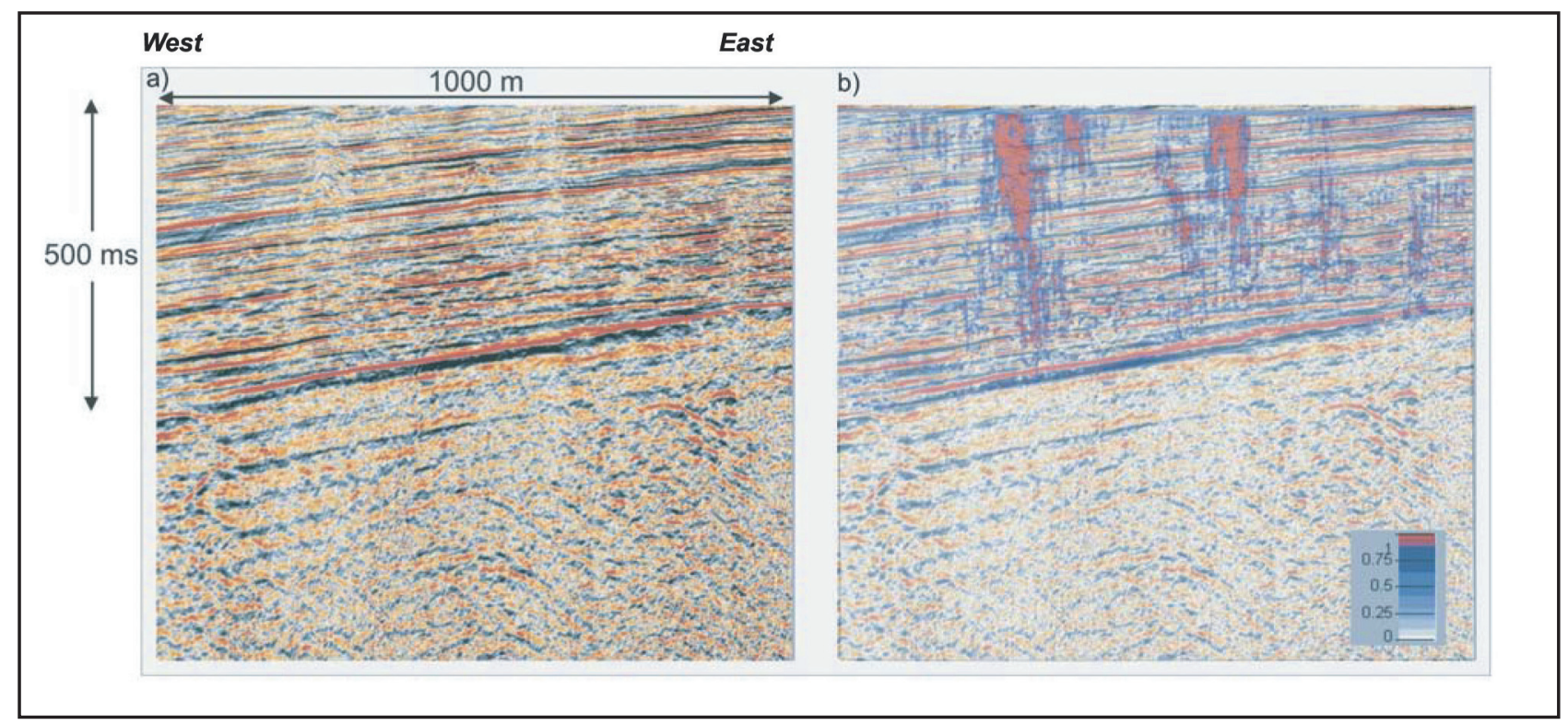

Figure 9. Example of gas leakage recognition using the neural network approach. The left side shows the original seismic data, the right hand side shows areas with seismic attributes indicative of gas seepage highlighted in red. The advantage of this technique is to pick up subtle features in a quantitative way.

rock interval (Figure 7). The transformation ratio evolution of this interval (Figure $7 \mathrm{a}$ ) demonstrates that the burial of the Aptian source rock on the shelf during the late Cretaceous, a time of declining but still enhanced heat flow, led to the maturation of the source rock up to levels of almost complete conversion (late oil window, early gas window). At the end of the late Cretaceous the erosion of approximately $800 \mathrm{~m}$ of sediment and the lack of any significant later burial cooled the source rock and resulted in the cessation of hydrocarbon generation ( $\mathrm{Tr}$ remains constant). This is also mirrored by the burial history of the area as shown in Figure 6a where maximum temperatures are reached during maximum burial in the late Cretaceous.

The Aptian source rock underlying the prograding Tertiary wedge in the outer shelf and slope area (Figure 7 b) shows an initiation of kerogen conversion coincident with the rapid late Cretaceous burial. However, as continuous sedimentation followed this period, the source rock continued to mature up to the present day (Figure $7 \mathrm{~b}$ ), reaching the end of the oil window at present.

The amount of additional transformation occurring during the Tertiary in this setting depends on the heat flow history, as investigated during sensitivity studies. Model runs assuming increasing degrees of stretching in the outer shelf and slope areas of the $2 \mathrm{D}$ section indicate that up to a beta factor of 4 in the area (and corresponding enhanced Cretaceous heat flow and longer time of heat flow decay) Cenozoic hydrocarbon generation occurs. At higher stretching factors the proportion of Cenozoic hydrocarbon generation becomes insignificant and the main generation event occurs during late Cretaceous time. The size and extent of the current active kitchen area depends, hence, strongly on the timing and amount of Tertiary burial in combination with the heat flow history used.

Although such models prove illustrative as to how the petroleum system may evolve, they are inherently difficult to validate without further exploration wells. However, the fact that ample evidence of natural gas seepage exists in the area points towards the presence of an active hydrocarbon kitchen.

\section{Hydrocarbon migration}

Systematic mapping of gas escape features in the seismic datasets and reproduction of these migration avenues using basin and fluid flow modelling can provide valuable information with respect to kitchen area location and petroleum migration dynamics. The mud volcanoes observed in the Orange Basin occur to the north of this study area (Ben Avraham et al., 2002). There is, however, substantial evidence of free gas within the margin strata in the study area's seismic data (e.g. Figure 8). Although these gas leakage events can be recognized visually, a more robust technique for identification of gas leakage is the use of trained neural networks to determine the probability that a seismic response is attributed to the presence of gas (Ligtenberg, 2005). Firstly, a neural network is trained to characterize the seismic response of ten seismic attributes in a region of no gas compared to a region that contains gas. The neural network is then applied to the rest of the seismic lines and the probability of gas being present is determined. In the example shown (Figure 9) the neural network provides a probability that any particular seismic wavelet corresponds to a gas event; this can be used to pick more subtle events that may not be visible to the human interpreter. The locations of gas leakage in the study area were determined by both visual interpretation as well as neural network-based analysis. 


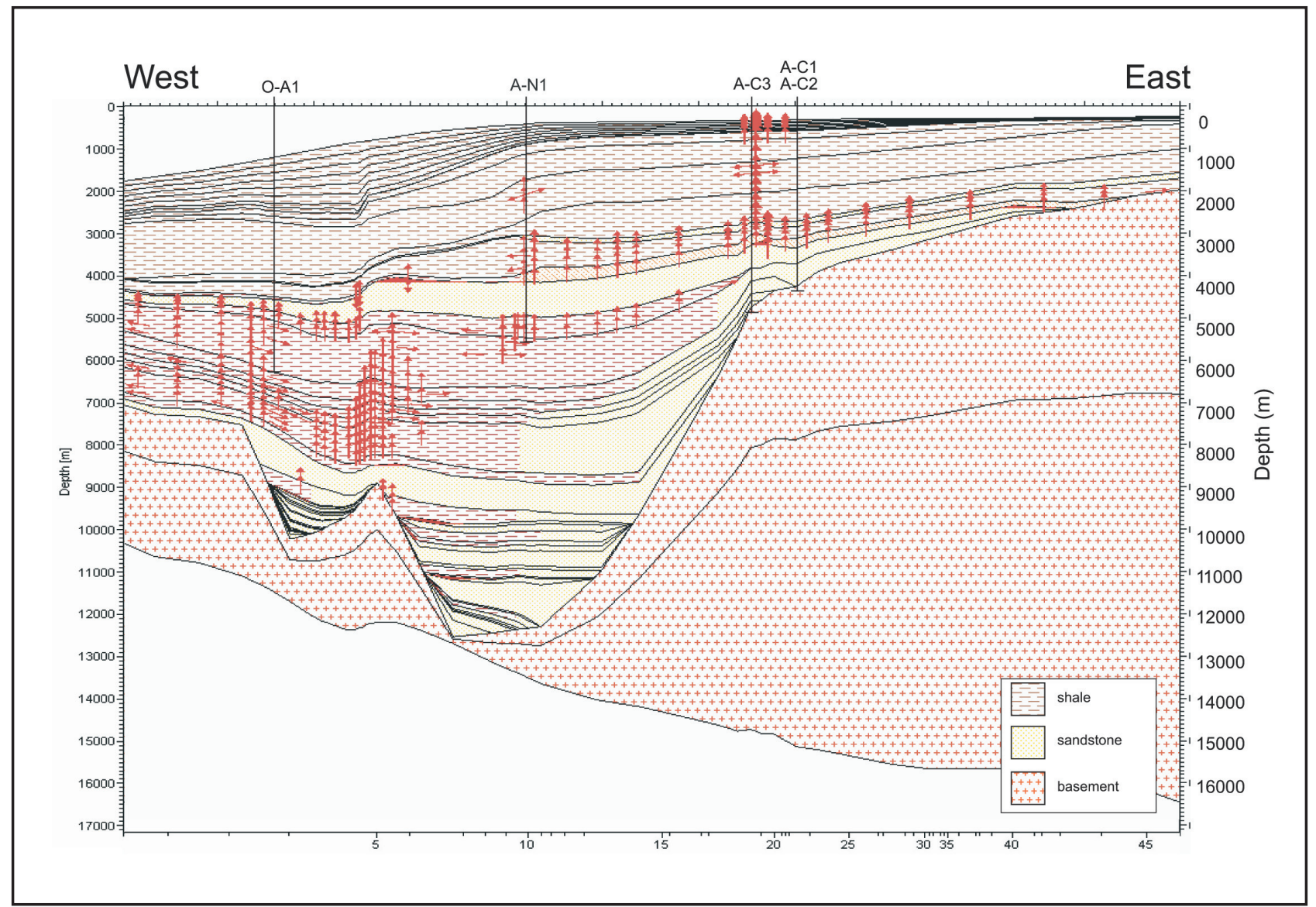

Figure 10. Model cross-section showing the results of the migration modelling at the present day. Hydrocarbon migration vectors are shown by the red arrows and can reproduce the associations observed in the seismic data (Figure 8).

In contrast to the mud volcanoes observed in the northern part of the Orange Basin (Ben Avraham et al., 2002), these leakage events were not confined to areas of faulting and were commonly dispersed events throughout much of the margin strata (Figure 8). In the study area they had both stratigraphic and structural associations (Figures $8 \mathrm{a}$ and b). The depth of origin of the observed gas chimneys as well as their relationship to geologic features indicates that a biogenic source of the gas is unlikely, as microbial activity is considered to be extremely limited if not completely absent at temperatures exceeding $80^{\circ} \mathrm{C}$ (Wilhelms et al., 2001). Additionally, Schmidt (2004) shows that the source of hydrocarbon gas desorbed from near-surface sediments offshore South Africa is of thermal origin.

In addition to the determination of the $\mathrm{Tr}$ of source rock intervals, the modelling also reveals hydrocarbon migration pathways and the prediction of leakage locations (Figure 10). The modelled leakage sites were then evaluated with regard to the gas leakage observations. In the model setup, the clay dominated overburden has to be permeable enough to enable gas that has been generated in the hydrocarbon system to migrate vertically within the model (leaky shale lithologic definition, table 3). Within the modelling package hydrocarbon migration is calculated using ray tracing in high-permeability carrier systems and Darcy flow in low permeability cap rock sequences. Additionally, source rock organic richness had to be increased in the 2D model such that sufficient amounts of hydrocarbons were generated to migrate through the model. Petroleum migration and leakage is clearly a 3D process where accumulations and eventual seal failure occur at the focal point of specific drainage areas. In order to reproduce such processes in $2 \mathrm{D}$ the source rock interval generating hydrocarbons has to be representative of the cumulative drainage area, obviously a scaling problem. In the case presented here the TOC values as listed in Table 2 provided sufficient hydrocarbons upon source rock maturation for migration to the surface.

The modelling reveals two primary processes responsible for gas leakage. The first is associated to petroleum accumulations that occur in structural closures where seal failure is the result of the hydrocarbon column overcoming the capillary entry pressure of the cap rock pores. The second process occurs at locations where leakage is associated with the vertical migration of gas through the cap rock system along fairways that are likely to be opened by an intermittent seal, such as the 15At1 shale, or where enhanced cap rock porosities and permeabilities occur. Such processes explain the predicted leakage in the middle and inner margin (Figure 10), which roughly 


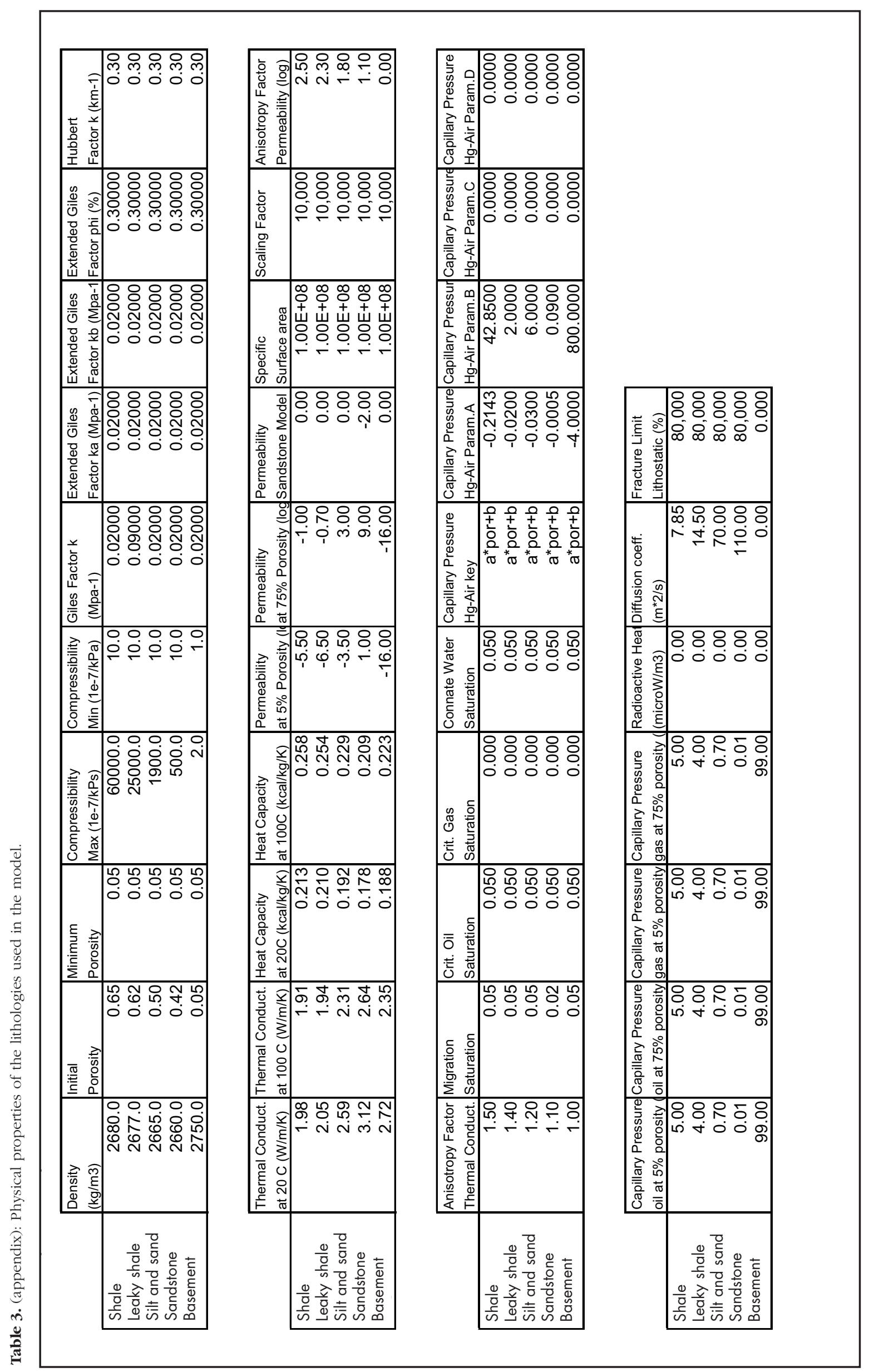


coincides with observed leakage locations. However, it must be kept in mind that realistic migration simulation should be performed in $3 \mathrm{D}$ than in $2 \mathrm{D}$ migration models. As our simulations lack the third dimension any prediction of petroleum accumulation must be seen as a possibility only. Never the less, even such 2D models allow the identification of probable processes controlling the spatial distribution of e.g. gas leakage positions. In our case the fact that the model predicts gas leakage at structural closures, carrier pinch outs and as a diffuse migration front through homogeneous claystone sequences where no intermittent carriers are defined indicates that the main physical processes controlling migration are being modelled correctly. Additionally significant migration vectors were only predicted in those simulations where hydrocarbon generation is taking place in the present time, i.e. in those cases where comparatively low stretching rates and hence heat flow histories were assumed. Our results indicate that an active kitchen area is required to reproduce present day gas migration observations. The extent of this kitchen depends on the heat flow model as well as on the amount and timing of Tertiary sedimentary wedge progradation. The only modelled source rock sequences within the hydrocarbon generation window in this setting are the Aptian and Barremian intervals. A potential Cenomanian/Turonian source rock would also fall within the favourable maturity interval. Cenozoic hydrocarbon generation, reaching values as high as $20 \%$ of the total potential of each source rock unit seems realistic (Figure 7).

\section{Conclusions}

- 2D petroleum system modelling revealed the maturation history for a west-east transect through the southen part of the Orange Basin.

- Source rocks of Jurassic and Cretaceous age have reached generally high levels of conversion.

- Peak source rock maturities on the shelf were reached during maximum burial (end of the Cretaceous). The following erosion cooled the source rocks such that hydrocarbon generation in this area ceased.

- Off the shelf break lack of late Cretaceous erosion combined with Tertiary progradation has led to a second phase of burial and maturation which is still ongoing today.

- Burial and erosion are the primary controls on source rock maturation in the area, while the heat flow history plays a secondary role.

- Gas migration and leakage were realistically predicted at comparatively low stretching rates and hence heat flow histories.

\section{Acknowledgements}

This project was funded as part of the INKABA ye AFRICA collaborative project. The authors would like to thank Schlumberger for the release of Petrel software license, IES GmbH, Germany, for the Petromod software, dGB for OpendTect software and TheChimneyCube ${ }^{\circledR}$ plug-in and Petroleum Agency, SA for data release. We would also like to thank the very constructive reviews from Naeth and Sachsenhofer. This is Inkaba yeAfrica contribution number 07 .

\section{References}

Barton, K.R., Muntingh, A. and Noble, R.D.P. (1993). Geophysical and geological studies applied to hydrocarbon exploration on the west coast margin of South Africa. Extended abstract of the Third International Congress of the Brazilian Geophysical Society, Rio de Janerio, Brazil. November 7-11 1993.

Ben Avraham, Z., Smith, G., Reshef, M. and Jungslager, E. (2002). Gas hydrate and mud volcanoes on the Southwest African continental margin off South Africa. Geology, 30, 927-930.

Brown, L.F., Brown, L.F. JR, Benson, J.M. and Brink, G.J. (1995). Sequence Stratigraphy in Offshore South African Divergent Basins, An Atlas on Exploration for Cretaceous Lowstand Traps by SOEKOR Limited. American Association of Petroleum Geology Studies in Geology, 41. 184pp.

Cole, D., Stewart, S.A. and Cartwright, J.A. (2000) Giant irregular pockmark craters in the Palaeogene of the Outer Moray Frth Basin, United Kingdom North Sea. Marine and Petroleum Geology, 17, 563-577.

Dimitrov, L.I., (2002). Mud volcanoes; the most important pathway for degassing deeply buried sediments. Earth-Science Reviews, 59, 49-76.

Dingle, R.V., (1983). Slump structures on the outer continental margin of southwestern Africa. In: A.W. Bally (Editor), Seismic expression of structural styles, a picture and work atlas, American Association of Petroleum Geologists Studies in Geology, 15, 24-30.

Gerard, I. and Smith, G.C. (1982). Post Paleozoic succession and structure of the southwestern African continental margin. In: J. S. Watkins and C. L. Drake (Editors), Studies in Continental Margin Geology. American Association of Petroleum Geology Memoir, 34, 49-74.

Heggland, R. (1997). Detection of gas migration from a deep source by the use of exploration 3D seismic data, Marine Geology, 137, 41-47.

Herbin, J.P., Muller, C., Graciansky, P.C. de Jacquin, T., Magniez-Jannin, F. and Unternehr, P. (1987). Cretaceous anoxic event in the South Atlantic. Revista Brasileria de Geociencia, 17, 92-99.

Hovland, M., and Judd, A.G. (1988). Seabed Pockmarks and Seepages. Graham and Trotman, London, United Kingdom, 293pp.

Hovland, M., and Thomsen, E. (1997). Cold-water corals - are they hydrocarbon seep related? Marine Geology, 137, 159-164.

Jungslager, E. (1999). Petroleum habitats of the Atlantic margin of South Africa. In: N.R. Cameron, R. H. Bate and V. S. V.S (Editors.), The oil and gas habitats of the South Atlantic, Geological Society, London, Special Publication, 153, 153-168.

Ligtenberg, J.H. (2005). Detection of fluid migration pathways in seismic data: implications for fault seal analysis. Basin Research, 17, 141-153.

Limonov, A.F., Weering, T.C.E.v., Kenyon, N.H., Ivanov, M.K. and Meisner, L.B. (1997) Seabed morphology and gas venting in the Black Sea mudvolcano area: Observations with the MAK1 deep-two sidescan sonar and bottom profiler. Marine Geology, 137, 121-136.

MacDonald, I.R., Buthman, D.B., Sager, W.W., Peccini, M.B. and Guinasso, N.L., Jr. (2000). Pulsed oil discharge from a mud volcano. Geology, 28, $907-910$.

Mazurenko, L.L., Soloviev, V.A., Belenkaya, I., Ivanov, M.K. and Pinheiro, L.M. (2002). Mud volcano gas hydrates in the Gulf of Cadiz. Terra Nova, 14, 321-329.

McKenzie, D. (1978). Some Remarks on the Development of Sedimentary Basins. Earth and Planetry Science Letters, 40, 25-32.

Milkov, A.V. (2000). Worldwide distribution of submarine mud volcanoes and associated gas hydrates. Marine Geology, 167, 29-42.

Muntingh, A., and L. F. Brown Jr. (1993) Sequence stratigraphy of petroleum plays, postrift Cretaceous rocks (lower Aptian to upper Maastrichtian), Orange basin, western offshore, South Africa. In: P. Weimer and H. W. Posamentier (Editors), Siliciclastic sequence stratigraphy - recent developments and applications, American Association of Petroleum Geologists Memoir, 58, 71-97.

Muntingh, A. (1993) Geology, prospect in Orange Basin offshore western South Africa. Oil and Gas Journal, 91, 105-109. 
Naeth, J., Di Primio, R., Horsfield, B., Schaefer, R.G., Shannon, P.M., Bailey, W.R., Henriet J.P. and (2005 Henriet J.P.). Hydrocarbon seepage and carbonate mound formation: A basin modelling study from the Porcupine Basin (offshore Ireland). Journal of Petroleum Geology, 28 147-166.

Parnell, J., (2002). Fluid seeps at continental margins; towards an integrated plumbing system. Geofluids, 2, 57-61.

Pepper, A.S. and Corvi, P.J. (1995a). Simple kinetic models of petroleum formation. Part I: oil and gas generation from kerogen. Marine and Petroleum Geology, 12, 291-319.

Pepper, A.S. and Corvi, P.J. (1995b). Simple kinetic models of petroleum formation. Part III: Modelling an open system. Marine and Petroleum Geology, 12, 417-452.

Pepper, A.S. and Dodd, T.A. (1995) Simple kinetic models of petroleum formation. Part II: oil to gas cracking. Marine and Petroleum Geology, 12, 321-340.

Schlüter, M. (2002). Fluid Flow in Continental Margin Sediments. In: G. Wefer, D. Billet, D. Hebbeln, B.B. Jørgensen, M. Schlüter and T. van Weering (Editors), Ocean Margin Systems, Springer-Verlag, Berlin, Germany, 205-217.

Schmidt, S (2004) The Petroleum Potential of the Passive Continental Margin of South-Western Africa - A Basin Modelling Study. Unpublished PhD dissertation, Fakultät für Georessourcen und Materialtechnik der Rheinisch-Westfälischen Technischen Hochschule Aachen, Germany, 182pp.

Sweeney, J.J. and Burnham, A.K. (1990). Evaluation of a Simple Model of Vitrinite Reflectance Based on Chemical Kinetics. American Association of Petroleum Geologists Bulletin, 74, 1559-1570.
Van der Spuy, D. (2003) Aptian source rock in some South African Cretaceous basins. In: T. J. Arthur, D. S. MacGregor and N. R. Cameron (Editors), Petroleum Geology of Africa: New Themes and Developing Technologies. Geological Society, London, Special Publication, 207, 185-202.

Van Rensbergen, P., de Batist, M., Klerkx, J., Hus, R., Poort, J., Vanneste, M., Granin, N., hlystov, O. and Krinitsky, P. (2002) Sublacustrine mud volcanoes and methane seeps caused by dissociation of gas hydrates in Lake Baikal. Geology, 30, 631- 634 .

Wefer, G., Berger, W.H. and Richter, C. (1998). Proceedings ODP, Initial. Reports, Texas A and M University, College Station, TX (Ocean Drilling Programme), 175, 569-577.

Wilhelms, A., Larter, S.R., Head, I., Farrimond, P., di Primio, R. and Zwach, C. (2001) Biodegradation of oil in uplifted basins prevented by deep-burial sterilization. Nature, 411, 1034-1037.

Wood, W.T., Gettrust, J.F., Chapman, N.R., Spence, G.D. and Hyndman, R.D. (2002). Decreased stability of methane hydrates in marine sediments owing to phase-boundary roughness. Nature, 420, 656-660.

Wygrala, B.P. (1989). Integrated study of an oil field in the southern Po basin, northern Italy. Forschungs zentrum Jülich reports, 2313.

Zimmerman, H.B, Boersma, A. and McCoy, F.W. (1987) Carbonaceous sediments and palaeoenvironment of the Cretaceous South Atlantic Ocean. In: J. Brooks and A. J. Fleet (Editors), Marine Petroleum Source Rocks. Geological Society, London, Special Publication, 26, 287-300.

Editorial handling: M. J. de Wit and Brian Horsfield 